Article

\title{
The Peculiarities of Low-Cost Carrier Development in Europe
}

\author{
Jolanta Sabaitytė ${ }^{1, *(\mathbb{C}}$, Vida Davidavičienè ${ }^{1}\left(\mathbb{D}\right.$ and Gerard Frederick Van Kleef ${ }^{2}(\mathbb{C}$ \\ 1 Department of Business Technologies and Entrepreneurship, Business Management Faculty, \\ Vilnius Gediminas Technical University, 10223 Vilnius, Lithuania; vida.davidaviciene@vgtu.lt \\ 2 Department of Traffic Analysis, Directorate of Railway Infrastructure, LG Infrastruktura LTD, \\ 02100 Vilnius, Lithuania; gerard-frederick.van-kleef@litrail.lt \\ * Correspondence: jolanta.sabaityte@vgtu.lt
}

Received: 15 October 2019; Accepted: 23 January 2020; Published: 3 February 2020

\begin{abstract}
Low-cost carriers (LCCs) have been growing by $11.4 \%$ in revenue passenger kilometers over 2017 and changed the airline industry radically. It drove down prices in the industry. Southwest Airlines (USA) designed the LCC blueprint model, and Ryanair copied it within Europe, followed by other airlines. This research aims to fulfill the gap in contemporary research upon LCC successfulness in Europe by a description of the current situation within Europe (2018 and January 2019) and the development issues it faced, which are mapped by the Ishikawa fishbone diagram. Furthermore, to rank the airlines on strength and vulnerability, The Technique for Order of Preference by Similarity to Ideal Solution (TOPSIS) methodology was used for meeting LCC characteristics and airline success. By comparison of meeting the LCC characteristics and the rank of the successfulness, the results of the TOPSIS analysis showed that the airlines meeting the most LCCs characteristics are seemingly less vulnerable to the development issues that airlines are facing, as Wizz Air and Ryanair are meeting most characteristics and are the most successful. Concluded is that airlines meeting the most LCC characteristics are the least vulnerable to current issues. However, major disruptions can still form an issue and limit growth. This research can be useful for comparing and positioning airlines in the market, based on issues and operational choices.
\end{abstract}

Keywords: low-cost carrier; development; airline industry; airline issues; transport industry; industry growth

\section{Introduction}

Low-cost carriers (LCCs) are a phenomenon that provided various people around the world access to air transportation with low prices, whereas in the past, aviation was known by its exclusivity for richer people and business travel. The airline industry has seen a big growth in its totality.

The number of passengers carried in 2017 grew by $7.2 \%$, whereas the revenue passenger kilometers (RPKs) on scheduled traffic in 2017 grew by $7.9 \%$. Also, freight transport by air grew in 2017. The freight tonne kilometers (FTKs) on scheduled flights grew 9.5\% [1].

The growth of the industry is ongoing since the last decline in 2009, with the number of passenger kilometers now approaching 8000 billion, whereas it used to be around 4500 billion in 2009 [2]. Besides the decline of 2009 and during other kinds of crises affecting the airline industry, it appears that the industry is growing exponentially in its overall trend after the end of World War II [1]. However, deregulations and freedom agreements are what caused the industry's growth in the first place. The Chicago Convention of 1944 led to a set of "freedoms" that are universal across the globe for providing international air travel. The first five freedoms are universal across the globe. The further four freedoms are provided only in special agreements [3]. Examples of deregulations and liberalization 
are the USA's Deregulation Act of 1978, the Open Skies Treaty between the European Union (EU), and the Single Skies of the EU that allowed competition to grow. It drove down prices and allowed (new) airlines to operate the routes they want.

So-called low-cost carriers with their total share of 30\% of carried passengers on scheduled flights caused a big portion of this growth in the airline industry. Their growth in 2017 was $11.4 \%$, which is about 1.5 times the size of the growth of the total number of passengers $[1,4,5]$.

The growth of this type of airline is remarkable and getting attention around the world. Southwest Airlines in the United States of America (USA) and Ryanair in Europe are the most well-known LCCs around the world. Their ability to grow has different reasons while operating a similar business model. Whereas Southwest mainly operates in the USA, which gave the airline the advantage of a big country with lots of destinations within this country, Ryanair just started to grow after the deregulation of the British Islands and later the EU [4]. However, growth is, like in many cases, not without issues.

The purpose of this article is to identify significant factors that influence the development of LCCs in Europe in 2018, combined with the current status of the airlines. This research aims to find the issues and risks airlines face, to find out which airline currently has the best business model for being profitable and able to grow, and can, for this reason, be an example for LCC development in the environment of 2018 in Europe. It is a novelty since it describes the issues that airlines face in 2017 and 2018, and how they compared in 2018. Hence, some airlines changed their model or went through changes. Also, it limits the article to the issues of this current period and will not describe the effects of the economic crisis of 2008 or the terrorist attacks of 11 September 2001; e.g., LCCs have the most effect on the prices and different types of LCC that have been developed. The tasks done during this research are literature research on definitions, business models, development, and issues of LCCs, specifically in Europe, to gather data from airlines about successfulness and what typical characteristics of LCCs have or do not have. The statistical model, technique for order of preference by similarity to the ideal (TOPSIS), is used to compare the selected airlines with each other and to rank these airlines according to best performing on business success factors and meeting the most LCC requirements. Methods used in the research are literature analysis, information comparison, grouping, visualization by Ishikawa's fishbone diagram, and TOPSIS calculation.

\section{Low-Cost Carrier Definitions and Concepts}

Low-cost carriers are, in many cases, defined by what they offer. Different names are also not uncommon, where names such as low-fare airlines [5], discount carriers [6], "price fighters" [7] and no-frills airlines [8] are used. However, the most generally accepted name is low-cost carrier [2], since it is the given name by the main organizations in the airline industry. The most common definition is "an air carrier that has a relatively low-cost structure in comparison with other comparable carriers and offers low fares or rates" [2]. Another one is, "Although marginally different, most researchers define LCCs as carriers which, through a variety of operational processes, have achieved a cost advantage over full-service carriers (FSCs)" [9].

The definition of the International Aviation Organization (2004) is similar to the one of Schlumberger and Weisskopf (2014) but is not pointing to other types of airlines.

Airlines make their own strategic and operational choices based on what they want to achieve. Low-cost carriers aim to have the lowest costs so that they can provide the lowest fares when the customer only pays for the basic product, which is transportation. All the other "frill" services, like the provided food or allowed checked-in luggage, must be paid for now [10]. According to Dennis (2007), this can speed up the turn-around of aircraft at airports, since aircraft do not need to be cleaned and catered at every airport. This will allow airlines to use their aircraft for more flights per day. As mentioned in the definitions above, it is to achieve a customer's preference for them because of the cost advantage. However, every LCC makes its own decisions. However, there are some models of low-cost carriers to distinguish. In the first place, there are the "pure LCCs," sometimes also referred 
to as ultra-low-cost carriers (ULCCs) [11]. This type of airline has to meet certain requirements in the research. These are:

1. Fleet homogeneity;

2. Single-class cabin;

3. Secondary airport;

4. Direct sales only;

5. No complimentary in-flight service with lowest fare category;

6. No complimentary in-flight service with highest fare category;

7. No free checked baggage with lowest fare category;

8. No free checked baggage with highest fare category;

9. No frequent flyer program;

10. Point-to-point services only;

11. No code-sharing;

12. One-way fares only;

13. No more than one fare at any time;

14. No more than two fares at any time [11].

Doganis (2009) [12] named point-to-point connections, uniform fleet, use of secondary airports, direct sales of tickets, one-way fares, and no-frills in services as typical characteristics. Klophaus, Conrady, and Fichert split fare categories in their requirements mentioned above, Besides the criteria mentioned above, the success of the airline can be assessed by some more, such as Earnings Before Interest, Taxes, Depreciation and Amortization (EBITDA) margin of the airline and load factor [13]. Airlines tend to have their growth ratio over the year in their annual reports [14].

Klophaus, Conrady, and Fichert (2012) also distinguished models of LCCs in their report, where they placed the LCCs in categories based on the number of criteria they met. These are:

- "Pure low-cost carriers," meeting at least 11 out of the 13 criteria;

- "Hybrid carrier with dominating LCC characteristics," between eight and 10 criteria;

- "Hybrid carrier with dominating full-service airline characteristics," between five and seven criteria;

- "Full-service carriers," 0 to four criteria. [11].

Given the rapid changes that the airline industry is going through, such as the earlier mentioned rapid growth, aircraft, and business development, the ideas of Klophaus, Conrady, and Fichert (2012) [13] are not completely relevant anymore for the situation in 2018. Some of the assessed airlines are not existing anymore or changed their business model. Recently, the Latvian airBaltic announced a switch over to a full Airbus A220-300 series fleet of at least fifty aircraft with options for 30 more aircraft [15]. But for example, as Klophaus, Conrady, and Fichert (2012) mentioned, this aircraft-type did not even exist. Additionally, the profitability and growth of the airlines in the research of Klophaus, Conrady, and Fichert (2012) are not taken into account since their focus was on characteristics.

The definitions and concepts are described above. However, airlines make their own decisions regarding their strategy and fleet. Some of these strategic decisions influence eventual sensitivity for some of the issues the airline industry can face, such as high oil prices. An assessment of meeting LCC criteria and successfulness of the airline (in EBITDA margin, growth, fleet size, and aircraft on order number of destinations) is done. Before this assessment, authors described the issues that airlines faced over the last year so that later authors could evaluate different strategies by the success and the possible effects of the issues in the industry.

\section{Issues Faced by Low-Cost Carriers from 2017 until December 2018}

The LCCs have been growing fast in Europe, and the whole airline industry has grown too. Besides growth and positive developments, there are also risks in the industry. It is important to 
identify the issues that can become risks to airline sustainability. In this research that is chosen for the years 2017 and 2018, the authors could identify the most recent issues. It is also a limitation so that "former" issues, such as effects of economic crises or terrorist attacks, are not taken into account, as mentioned in the introduction. This analysis was conducted by literature research that was later summarized and structured by using the method of the Ishikawa diagram [16].

LCCs faced issues in these years. Most notably have been the strikes at Ryanair, where pilots are striving to have a better salary, good base locations, and working hours. It caused cancellations and lots of damage to the reputation of the airline. Ryanair keeps on growing but gave a profit warning to its shareholders [17]. Ryanair started giving in to the desires of some of the labor unions. Ryanair's problems seem to stay by just the company itself [18]. It is one of the examples why it is important to point out briefly what the issues were, and the reasons for the issues.

Monarch, Air Berlin, and Primera Air went to bankruptcy recently [19]. Primera Air, as the most recently fallen airline, filed for bankruptcy, while it just started operating new aircraft and new routes. However, the airline was not prepared to withstand the losses it made. New aircraft deliveries caused the airline to lease other aircraft, but since they promised their low prices, it got into trouble. The leasing costs of the other aircraft were very high, most likely since the airline had to do it in the middle of the summer [20].

Air Berlin lost its main investor and was doomed to file for bankruptcy. Air Berlin tried to brand itself as LCC, but it was more an FSC with a few LCC characteristics [11]. After years of losses, Etihad stopped investing in the airline, which meant that Air Berlin had to carry the losses by itself [21].

Another factor that can be an issue in the future is the limited capacity available. The capacity is that some of the airports are getting close to their maximum capacity, like Amsterdam Schiphol Airport [22]. Given that the airports are located close to the cities in most cases, space to expand can be limited. This means that a slot on these airports is getting more expensive by the lack of supply. However, the demand for air transportation of passengers is increasing, since globalization is still ongoing. Growth within the air freight market is also noticeable. This will tighten the airports even more in their number of slots [23].

One other issue, which is universal for all the airline industry, is the oil price. Fuel is the highest cost for an airline, followed by personnel cost. However, the airlines found a way to limit the fluctuation by hedging the costs. The real issue is the hedging itself. Due to the continuous fluctuation of the oil price, it can be that the hedged price for the fuel can lead up to higher costs than necessary when the prices go down [24]. However, LCCs seem to be less affected due to their younger, more efficient fleet than FSCs [25].

Flight taxes can put a hold on growth and low prices. Ryanair is known for its really low prices from around $10 €$. This situation is becoming more difficult when a country implements a flight tax with a fixed number of euros. Some countries implemented flight taxes based on distance. This tax affects traffic patterns, where airlines need to adjust. For an airline, taxes can be a reason why some destinations are not interesting to fly to [26].

The described issues above seem to be coming from different categories, which may be grouped into personnel, machines, material, and environment, according to Ishikawa's original fishbone diagram [16]. In this research, the Ishikawa diagram is used as a tool to map the issues of the airline industry into the factors that affect the airline industry. Ryanair went into a labor dispute with its pilots, which led to strikes (personnel). After a short life as an LCC, Primera Air filed for bankruptcy since the supplier of aircraft, Airbus, was late with their delivery (machines). Primera Air already planned forward on having these aircraft, so they had to find replacement lease aircraft to carry out their promised services. This led to their fate of filing for bankruptcy. It shows how difficult it can be to enter the market and to maintain the position. Air Berlin had to file for bankruptcy after the stop of investments from Etihad Airways (material), and airlines had to deal with higher fuel prices (material). Slot problems are mainly due to a lack of capacity at airports or limitations in slots 
(environment). The causes led to the development issues are summarized by the following diagram (Figure 1), according to the model of Ishikawa [16].

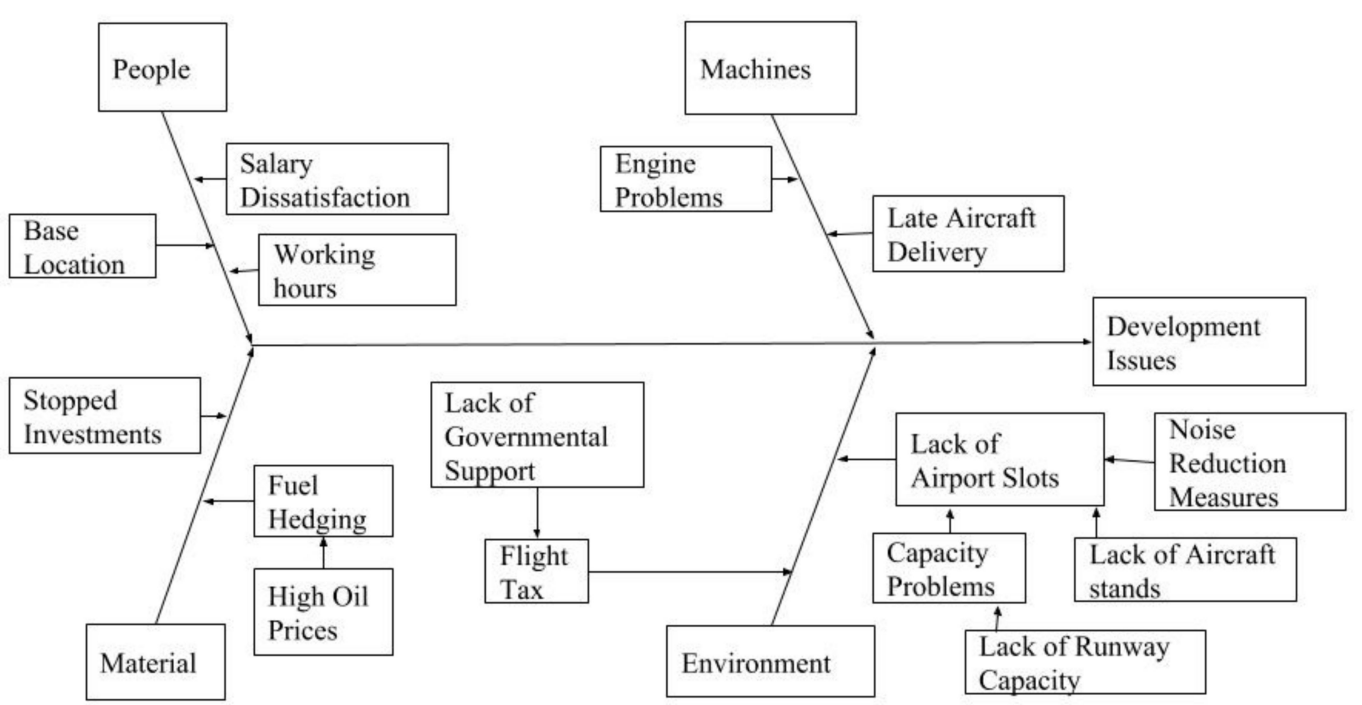

Figure 1. Ishikawa diagram of the airline development issues. Source: compiled by authors based on issues described in the article.

In Figure 1, it is visible that there are four different types of (development) air transport issues that can be encountered by low-cost carriers within the period from 2017 and 2018, and can lead to development issues. There is, for example, a period of economic growth, where the countries in the EU had an average growth of $2.8 \%$ [27]. However, this means that airlines need to be able to grow in a time when there is economic growth [28]. An assessment of airlines is based on the need for airlines performance analysis following the LCC criteria. The airlines all can face some of the issues mentioned above, in the future, or face these issues already; for that reason, it is necessary to see how their business model has succeeded. In order to analyze the successfulness of the business model, it is necessary to research which characteristics of LCCs the airlines meet.

\section{Methodology}

This research aims to give an overview of the airline industry's issues regarding the growth, development, and sustainability of the airline industry. This is combined with how airlines are currently performing and what LCC criteria they meet, so that can be compared generally in which airlines can sustain future issues.

The structure of the research consisted of five processes, as shown in Figure 2. The processes were supplied with information through input from literature, annual reports, and databases. Analysis of the literature revealed the definition of LCCs and describes the issues faced in the airline industry, and forms a list for the main characteristics of LCCs. The issues faced were mapped into the Ishikawa diagram, where the issues were grouped by the affected factors of the airline process. The main characteristics of the LCCs provide input to the first TOPSIS, which compares the business models of the airlines on how they are meeting the listed LCC-characteristics. Annual reports and data from databases form the input of the second TOPSIS, which focused on growth, EBITDA, and efficiency of the airline. The output of both TOPSIS processes were mapped into a quadrant diagram, which shows how the airlines are meeting the characteristics and how successful they are. 


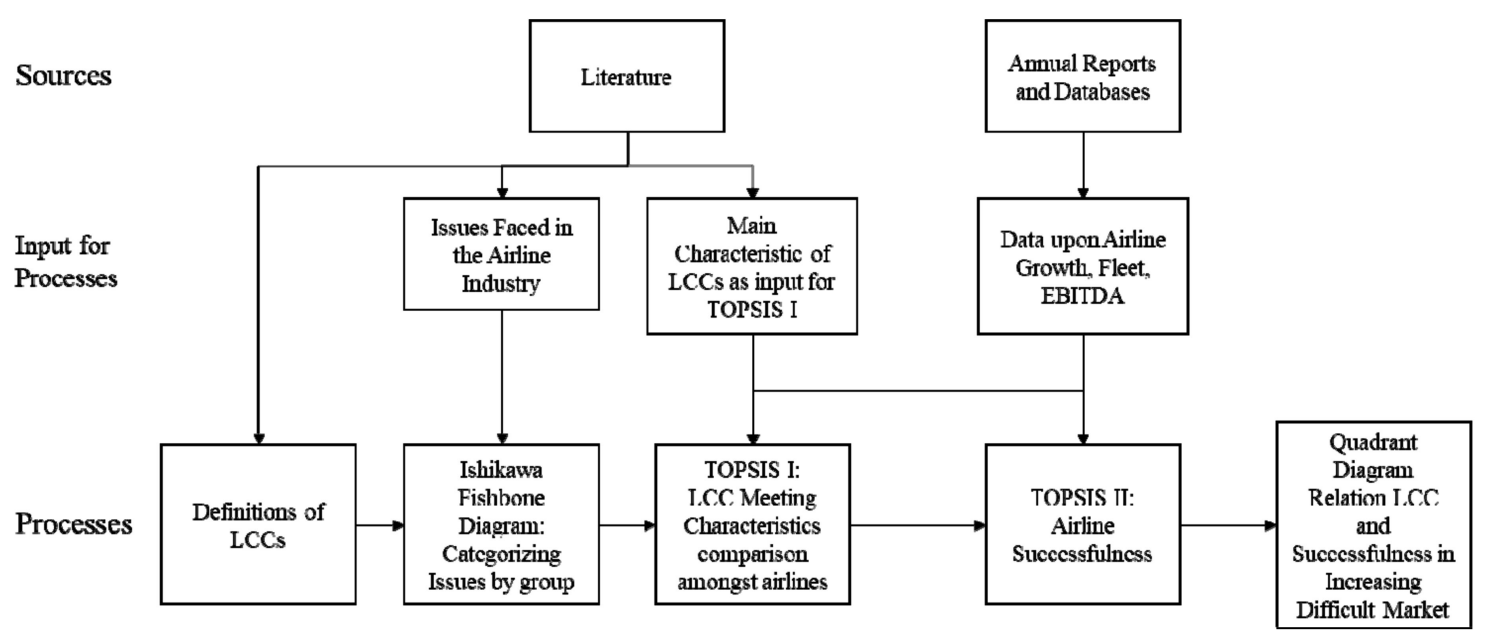

Figure 2. Diagram of research structure. Compiled by the authors.

The airline development issues described above were put into an Ishikawa diagram (see Figure 1) for providing an overview. For an airline, it is then important to see how it can withstand some of the issues, and what can be affecting the airlines. For example, The International Air Transport Association (IATA) (2018) says that airlines try to counter the fuel price increase not only with fuel hedging but with fuel efficiency provided by new, efficient aircraft. Therefore, an airline has a low average fleet age, preferably. Moreover, airlines that mainly fly to secondary airports generally have more space to grow there than at a major European hub. Therefore, it is important to see how the airlines operate and what their success is in the environment of 2017 (financial results, yearly averages) and 2018 (fleet characteristics, operating model). What can be seen from IATA's statement is that multiple criteria have to be met by an airline to withstand issues in the industry. Focus is on how well the airlines are meeting the criteria of the operating model of an LCC, which is combined with a criteria analysis upon the airlines' success.

The methodology used to assess if the airline is meeting the LCC definition criteria and the LCC development's success is the technique for order preference by similarity to the ideal solution (TOPSIS) from where the outcome leads to a ranking of alternatives, in this case, the airline's business model. The assessment exists of different criteria and numbers and it can, therefore, be seen as fuzzy data analysis. This needs to be approached by a multiple criteria decision method (MCDM). Normally, TOPSIS is meant for ranking alternatives in decisions, but it can be used for ranking models, too. Hence, the TOPSIS method was based on a set of criteria and situations. TOPSIS is preferred over simple additive weighting since it can handle negative data in its calculations. This is required since airlines can decline, make losses, and sell aircraft. Based on the fuzzy dataset, the methodology TOPSIS was chosen to rank the airlines to identify the successful airlines in the market. This led to an output that shows if meeting LCC criteria can lead to more successfulness and lower vulnerability. The two rankings were presented together in a quadrant diagram. In Table 1, the criteria used in the two TOPSIS analyses in Tables 2-5 are presented. In this way, the split was done between the earlier mentioned criteria [29].

The TOPSIS analysis was based on retrieved data regarding meeting the LCC criteria, as well as the airlines' successfulness in growth (in passengers), efficiency (seat occupancy, fleet age), and EBITDA. The data used for the analyses are presented below in Tables 2 and 4 . This was the input to the TOPSIS calculations on meeting the LCC requirements in Table 2 and the success in Table 4. TOPSIS requires normalized data for the statistics, so the numbers in the table needed to be normalized by the following formula [29]:

$$
N_{i j}=\frac{X_{i j}}{\sqrt{\sum_{i=1}^{m} X_{i j}^{2}}},
$$


where $N$ is the normalized number, $X$ is the given number, $i$ is the value of the alternative in relation to the criterion, and $j$ marks the criterion involved in the calculation.

Since TOPSIS is based on weights, the normalized numbers in the table were multiplied by the assigned weight given for the concerned criterion. After this multiplication, the highest and the lowest numbers were visible. After this, the positive and negative ideal per criterion were calculated. Before this, what is positive and negative needed to be established. A high EBITDA margin is positive, but a high average fleet age is negative. The following formula was used to calculate the positive and negative ideal [29]:

Positive:

$$
V^{+}=\left(V_{1}^{+}, V_{2}^{+}, \ldots, V_{n}^{+}\right)=\left(\left(\frac{\max _{i} i j}{j \in J i}\right)\left(\frac{\min _{i} i j}{j \in J i}\right)\right),
$$

Negative:

$$
V^{-}=\left(V_{1}^{-}, V_{2}^{-}, \ldots, V_{n}^{-}\right)=\left(\left(\frac{\min _{i} i j}{j \in J i}\right)\left(\frac{\max _{i} i j}{j \in J i}\right)\right)
$$

where $V^{+}$is the positive ideal and $V^{-}$is the negative ideal.

When the positive and negative ideals per criterion were calculated, the TOPSIS method proceeded with the calculation of the distance of each alternative to the positive and negative ideal. In this case, each airline's normalized weighted number for each criterion was compared to the positive and negative ideal by using the following formulas:

Distance to Positive:

$$
S_{i}^{+}=\sqrt{\sum_{j=1}^{n}\left(V_{i j}-V_{j}^{+}\right)^{2}}
$$

Distance to Negative:

$$
S_{i}^{-}=\sqrt{\sum_{j=1}^{n}\left(V_{i j}-V_{j}^{-}\right)^{2}}
$$

where $S_{i}^{+}$is the distance to the positive ideal solution and $S_{i}^{-}$is the distance to the negative ideal solution.

The goal of the application of the TOPSIS was to provide an order preference for similarity to the ideal solution. In this case, it is how the airlines are meeting the LCC criteria and how successful the airlines are, as mentioned in Table 1. For this final calculation, this formula was used [29]:

$$
P_{i}=\frac{S_{i}^{-}}{S_{i}^{-}+S_{i}^{+}}
$$

where $P_{i}$ is the biggest similarity to the negative solution.

The closest result to a value of one is the most similar to the best solution, which in this research is the airline that meets the highest number of LCC criteria and that is the most successful in terms of profitability, growth, network size and fleet age. The closest to 0 is the most similar to the worst solution, which is a vulnerable airline for eventual issues that occur, which means an airline can have an old fleet or is making losses at the moment. TOPSIS is a method to compare alternatives based on criteria [29]. In this research, airlines form the "alternatives."

The LCC criteria mentioned by Doganis (2009) and airlines was assessed by Klophaus, Conrady, and Fichert (2012). Miranda, Baltazar, and Silva (2016) formed the base for the analysis of success. The EBITDA margin was chosen since this provides the operating profit margin, not including taxes, interests, or depreciation and amortization of the airline of the revenue they make [13]. It was also chosen since it does not include taxation since that can be different in each country. 
Table 1. Criteria for TOPSIS analysis.

\begin{tabular}{|c|c|}
\hline Criteria TOPSIS LCC Criteria & Criteria TOPSIS Successfulness \\
\hline $\begin{array}{l}\text { The ratio of aircraft of the same type, measured by dividing the } \\
\text { biggest group of aircraft in the fleet by the total fleet (C1) }\end{array}$ & $\begin{array}{l}\text { Aircraft on order and in memoranda of } \\
\text { understanding (as of } 1 \text { December 2018) (C12) }\end{array}$ \\
\hline $\begin{array}{l}\text { Rather using airports ranked as secondary airports, avoid } \\
\text { flying to Paris Charles de Gaulle and London Heathrow }(\mathrm{C} 2)\end{array}$ & Average fleet age (as of 1 December 2018) (C13) \\
\hline $\begin{array}{l}\text { Direct sales of the airline tickets via the airline's own website is } \\
\text { the most common (C3) }\end{array}$ & Number of destinations (C14) \\
\hline One-way fare tickets are the main way to sell tickets (C4) & $\begin{array}{l}\text { The profitability of airline } \\
\text { (EBITDA margin in \%) (C15) }\end{array}$ \\
\hline $\begin{array}{l}\text { No usage of jet bridges (unless required) (C5) } \\
\text { No included onboard services on Short-haul (C6) } \\
\text { No frequent flyer program (C7) }\end{array}$ & Average load factor of 2017 in \% (C16) \\
\hline No free checked baggage (C8) & Average growth/decline figure \\
\hline No code sharing (C9) & over 2017 in \% (C17) \\
\hline No cargo license (C10) & \\
\hline $\begin{array}{l}\text { No guaranteed connections to another flight (of the carrier } \\
\text { itself or cooperating airlines) (C11) }\end{array}$ & \\
\hline
\end{tabular}

All the criteria mentioned were based on the definitions given on what a real LCC or ULCC should be like. Since defining a secondary airport is hard, it was chosen to have a limited look at the airports serving Europe's two most populated functional urban areas, which are London and Paris [30]. Airlines can differ from them in their strategy. However, in that way, they were not meeting the real definitions or requirements. Definition criteria were equally weighted, whereas successfulness criteria, i.e., profitability, growth, and the number of destinations offered were given a higher weight. It was based on an assumption of what is important.

Klophaus, Conrady, and Fichert (2012) assessed 20 airlines for their simple LCC index, based on the 20 largest LCC, ranked by capacity [31]. Some of these airlines no longer exist. Other airlines focus on one country, rather than having bases in more countries. Within this research, the airlines Ryanair, easyJet, Eurowings, Norwegian, Vueling, Wizz Air, airBaltic, and Transavia were chosen based on the following factors:

- $\quad$ Named as LCC by Deutsches Zentrum für Luft- und Raumfahrt (2010);

- Flying with aircraft that are capable of carrying at least 130 passengers;

- Bases in more than one EU country;

- $\quad$ Still active on 20 November 2018;

- $\quad$ Assessed on winter schedule 2018-2019.

The quadrant diagram shows the positions of the different airlines regarding successfulness and meeting the LCC criteria. The axes are successful, vulnerable (vertical), and "hybrid carrier/FSC or True" LCC. The quadrants wherein the airlines can be located:

- $\quad$ True LCC, successful;

- True LCC, vulnerable;

- Hybrid carrier/FSC, successful;

- Hybrid carrier/FSC, vulnerable.

This shows how the different operating models of the airlines can lead to successfulness.

\section{Results-Data Gathering and Processing by Applying TOPSIS}

For the assessment in TOPSIS, whether airlines are meeting LCC requirements, it is important to systemize the knowledge and to construct the table. In the case of yes-or-no answers to the question, if a requirement is met, then the answer will be 1 (yes) and 0 (no). Fleet similarity (as of 30 November 2018) and the different LCC characteristics are described in Table 2. Wizz Air, Transavia, and Vueling are 
the only airlines that operate a complete one-type fleet of only Airbus A320-family- and Boeing 737-family-type aircraft. Operating a one-type fleet is one of the main characteristics of an LCC and provides several operational benefits in maintenance, training, and flexibility [11]. The data of flying from London Heathrow and or Paris Charles de Gaulle shows that only three of the eight airlines avoid these airports [32]. By browsing for a flight from each assessed airline, the main booking option via the airline's website was ranking the highest with the best price offer. The flights used for this research were:

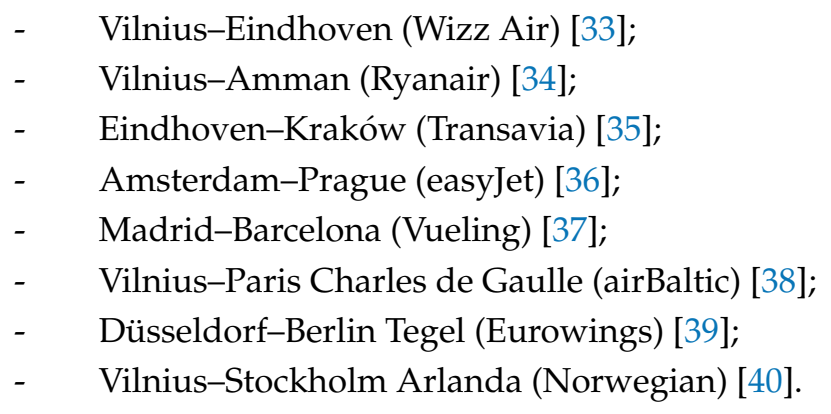

Skyscanner is a neutral website that aims to discover the lowest prices on flights, and the cheapest options for the flights were in the first place in the offers for the same flight. Eurowings, Vueling, and Transavia flights are also code-sharing, mainly with (partners of) their parent companies, such as Lufthansa Group, IAG, and Air France-KLM.

Via the airline websites, it became clear that every airline first provides the one-way services, and showed the frequent flyer programs [41-48]. In the case of Eurowings, Vueling, and Transavia, it is the same as their parent company. The analysis of airline website contents also revealed that food and drinks are not available "for free" on short- and medium-haul flights of the airlines. Ryanair and easyJet changed their business model slightly $[49,50]$. They started providing connections and cooperation with other long-haul carriers. This is part of changed and adjusted strategies.

Table 2. Input for TOPSIS LCC criteria. Source: compiled by the authors.

\begin{tabular}{|c|c|c|c|c|c|c|c|c|c|c|c|}
\hline Criteria & $\begin{array}{c}\text { C1 } \\
{[50]}\end{array}$ & $\begin{array}{c}\mathrm{C} 2 \\
{[51]}\end{array}$ & $\begin{array}{c}\text { C3 } \\
{[33-40]}\end{array}$ & $\begin{array}{c}\text { C4 } \\
{[41-48]}\end{array}$ & $\begin{array}{c}\text { C5 } \\
{[52-59]}\end{array}$ & $\begin{array}{c}\text { C6 } \\
{[41-48]}\end{array}$ & $\begin{array}{c}\text { C7 } \\
{[41-48]}\end{array}$ & $\begin{array}{c}\text { C8 } \\
{[41-48]}\end{array}$ & $\begin{array}{c}\text { C9 } \\
{[33-40]}\end{array}$ & $\begin{array}{l}\text { C10 } \\
{[60]}\end{array}$ & $\begin{array}{c}\text { C11 } \\
{[41-50]}\end{array}$ \\
\hline Weight & 0.091 & 0.091 & 0.091 & 0.091 & 0.091 & 0.091 & 0.091 & 0.091 & 0.091 & 0.091 & 0.091 \\
\hline Wizz Air (W6) & 1.000 & 1 & 1 & 1 & 1 & 1 & 1 & 1 & 1 & 1 & 1 \\
\hline Ryanair (FR) & 0.994 & 1 & 1 & 1 & 1 & 1 & 1 & 1 & 1 & 1 & 0 \\
\hline Transavia (HV) & 1.000 & 1 & 1 & 1 & 0 & 1 & 0 & 1 & 0 & 0 & 0 \\
\hline easyJet (U2) & 0.997 & 0 & 1 & 1 & 0 & 1 & 1 & 1 & 1 & 1 & 0 \\
\hline Vueling (VY) & 1.000 & 0 & 1 & 1 & 0 & 1 & 0 & 1 & 0 & 0 & 0 \\
\hline airBaltic (BT) & 0.400 & 0 & 1 & 1 & 0 & 1 & 0 & 1 & 0 & 0 & 0 \\
\hline Eurowings (EW) & 0.748 & 0 & 1 & 1 & 0 & 1 & 0 & 1 & 0 & 0 & 0 \\
\hline Norwegian (DY) & 0.802 & 0 & 1 & 1 & 0 & 1 & 0 & 1 & 1 & 0 & 0 \\
\hline
\end{tabular}

The data in Table 2 and the result of the calculation in Table 3 prove that Wizz Air is meeting all the LCC requirements, whereas airBaltic is meeting only the ones that every researched airline is meeting. Wizz Air is in this way ranking first, followed by Ryanair and easyJet, that both started following some different principles in the time between the publication of Klophaus, Conrady, and Fichert (2012) and today. Wizz Air is, according to this research, the single "true" LCC. The TOPSIS calculations in Tables 4 and 5 show which airline is the most successful, both financially and in terms of growth. The calculation towards the results in Table 3 can be found in Appendix A.

The data presented in Table 4 show that all of the airlines grew in 2017. This varied between $6.5 \%$ and $77 \%$. However, the $77 \%$ for Eurowings was caused by the acquisition of the remains of the fallen Air Berlin [61]. The most noticeable data in Table 3 are the aircraft on order by Wizz Air, the complete fleet replacement by airBaltic, the high load factor, and the high EBITDA margin of Ryanair. Norwegian is the only airline in this research that reported a loss, which means that its operating costs are exceeding the revenue made. All of the data upon the criteria are placed in Table 4 . In Table 5 the 
results of the calculations can be found, whereas the calculations of the successfulness can be found in Appendix B.

Table 3. Results of TOPSIS LCCcriteria. Source: compiled by the authors.

\begin{tabular}{ccccc}
\hline Airline & $\boldsymbol{S}_{\boldsymbol{i}}{ }^{+}$ & $\boldsymbol{S}_{\boldsymbol{i}}{ }^{-}$ & $\boldsymbol{P}_{\boldsymbol{i}}$ & Rank \\
\hline Wizz & 0 & 0.15 & 1 & 1 \\
Ryanair & 0.091 & 0.122 & 0.573 & 2 \\
Transavia & 0.141 & 0.06 & 0.287 & 4 \\
easyJet & 0.123 & 0.090 & 0.421 & 3 \\
Vueling & 0.151 & 0.022 & 0.126 & 6 \\
airBaltic & 0.150 & 0 & 0 & 8 \\
Eurowings & 0.151 & 0.013 & 0.077 & 7 \\
Norwegian & 0.144 & 0.048 & 0.249 & 5 \\
\hline
\end{tabular}

Table 4. Input for successfulness TOPSIS. Source: compiled by the authors, see footnotes.

\begin{tabular}{ccccccc}
\hline Criteria & $\begin{array}{c}\mathbf{C 1 2} \\
{[62-69]}\end{array}$ & $\begin{array}{c}\mathbf{C 1 3} \\
{[61]}\end{array}$ & $\begin{array}{c}\mathbf{C 1 4} \\
{[15,70-77]}\end{array}$ & $\begin{array}{c}\mathbf{C 1 5} \\
{[14,59,69,78-82]}\end{array}$ & $\begin{array}{c}\mathbf{C 1 6}^{\mathbf{1}} \\
{[14,59,69,78-82]}\end{array}$ & $\begin{array}{c}\mathbf{C 1 7}^{\mathbf{2}, 3} \\
{[14,59,69,78-82]}\end{array}$ \\
\hline Weight & 0.1 & 0.05 & 0.15 & 0.4 & 0.1 & 0.2 \\
Wizz Air & 257 & 4.7 & 146 & 14.1 & 91.2 & 24 \\
Ryanair & 135 & 6.9 & 243 & 20 & 95.3 & 10.3 \\
Transavia & 0 & 8.2 & 115 & 5.6 & 90.6 & 11 \\
easyJet & 147 & 7.3 & 163 & 8.1 & 92.9 & 10.2 \\
Vueling & 45 & 7.2 & 112 & 12.7 & 84.7 & 6.5 \\
airBaltic & 36 & 9.4 & 70 & 5.8 & 76 & 22 \\
Eurowings & 4 & 11.1 & 137 & 2.3 & 79.91 & 771 \\
Norwegian & 116 & 3.9 & 161 & -5.75 & 87.5 & 13 \\
\hline
\end{tabular}

${ }^{1}$ Ryanair, easyJet, and Wizz Air work with a broken fiscal year (FY). The profit margin given is the one of FY that covered the most of 2017. ${ }^{2}$ Eurowings is put in the same group as Brussels Airlines in Lufthansa Group's Annual Report. The load factor given in this table is the one of Eurowings and Brussels Airlines combined. ${ }^{3}$ Eurowings grew by $77 \%$, mainly due to Lufthansa group's acquisition of the parts of Air Berlin.

Table 5. Results successfulness TOPSIS. Compiled by the authors.

\begin{tabular}{ccccc}
\hline Airline & $\boldsymbol{S}_{\boldsymbol{i}}{ }^{+}$ & $\boldsymbol{S}_{\boldsymbol{i}}{ }^{-}$ & $\boldsymbol{P}_{\boldsymbol{i}}$ & Rank \\
\hline Wizz Air & 0.149 & 0.276 & 0.650 & 2 \\
Ryanair & 0.158 & 0.346 & 0.687 & 1 \\
Transavia & 0.258 & 0.150 & 0.368 & 7 \\
easyJet & 0.225 & 0.189 & 0.457 & 4 \\
Vueling & 0.204 & 0.243 & 0.544 & 3 \\
airBaltic & 0.243 & 0.156 & 0.391 & 6 \\
Eurowings & 0.247 & 0.195 & 0.441 & 5 \\
Norwegian & 0.372 & 0.052 & 0.122 & 8 \\
\hline
\end{tabular}

From this TOPSIS calculation and its result in Table 5, it can be concluded that Ryanair has the highest rank, whereas Norwegian is ranked last. This ranking tells that Ryanair is the best performing LCC, by being the most similar to the positive ideal solution, which is a growing, profitable, (fuel-) efficient airline. This is mainly caused by its high EBITDA, as well as a young, nearly single-type fleet of aircraft, as well as its high seat occupancy. Newer aircraft are more fuel efficient and have a single-type fleet that allows the company to save on crew (all the crew able to operate all the aircraft in the fleet) and maintenance costs (the maintenance crew only needs to have knowledge on one aircraft type and the airline does not need to maintain a stock of different aircraft types). High seat occupancy is a key performance indicator for airlines since this determines how well the provided capacity is used to create revenue. Norwegian is the only airline making a loss amongst this group and had to sell new aircraft to pay bills. Noticeable is that the "subsidiary LCCs," such as Eurowings, Vueling, 
and Transavia, are not amongst the highest in meeting LCC criteria and also not in the successfulness TOPSIS. A probable reason for this is that they mainly operate out of main airports, operate an older fleet, and have lower load factors than the airlines that are meeting more LCC criteria. The older fleet can cause less efficient aircraft and higher vulnerability when the oil price rises. In Figure 3, the data presented shows how the airlines compare to each other, based on the overall score on both TOPSIS analyses. Wizz Air and Ryanair are the least vulnerable to the industry's problems, given their successfulness and growth (perspectives). Norwegian is the most vulnerable.

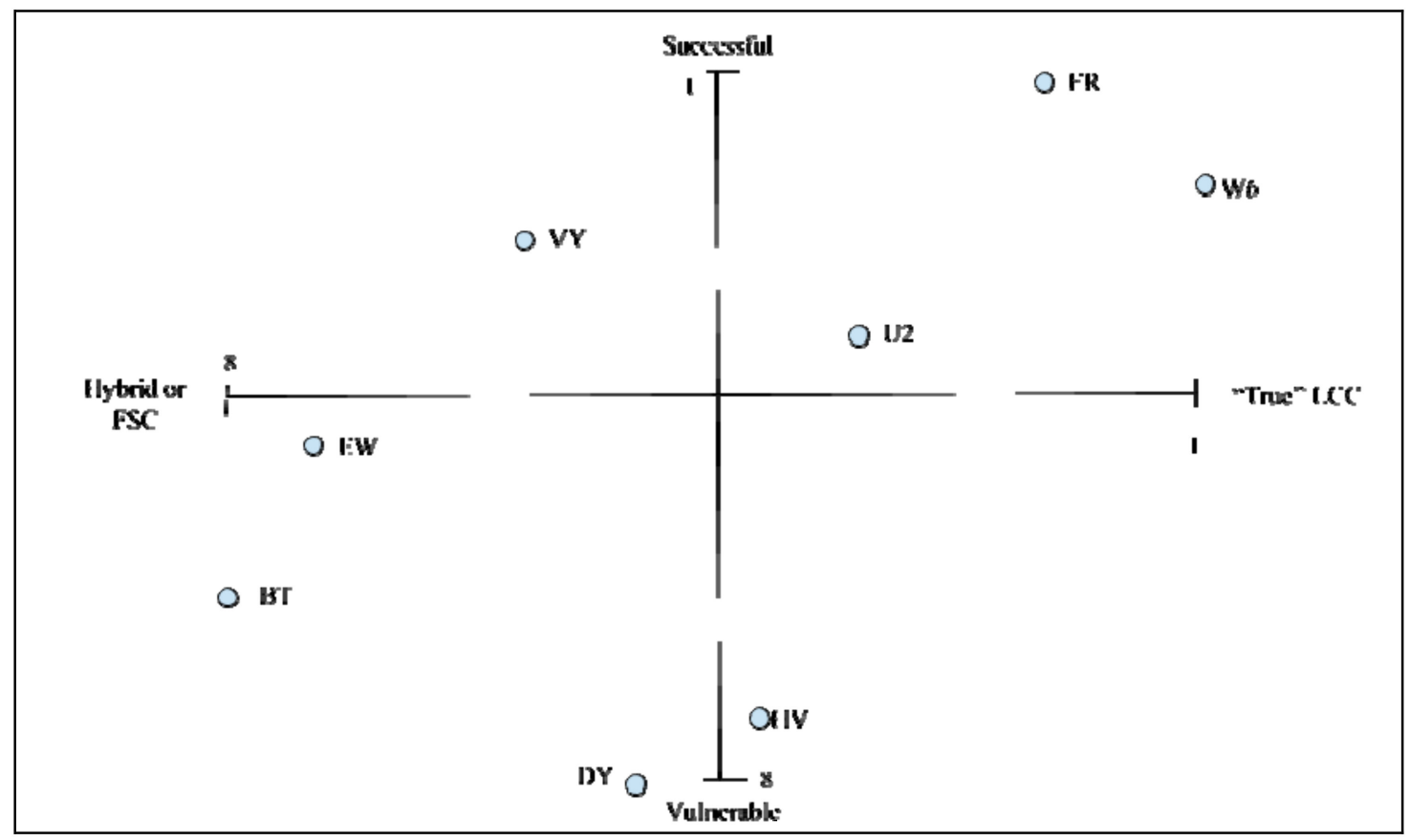

Figure 3. Quadrant diagram results of TOPSIS Source: compiled by the authors.

From the compiled quadrant diagram, it can be concluded that Ryanair and Wizz Air are the two airlines that are the most successful and meet the most LCC criteria. Also located in the "True LCC"-Successful quadrant, easyJet is the fourth most successful airline in this research. Based on this final result, it can be stated that the chances for a listed LCC to be successful are mainly based on how many criteria they meet to become a true LCC. Independence also seems to have an influence, as both Eurowings and Transavia are on the vulnerable side. Vueling is the only airline that is not meeting the majority of the LCC criteria and is a successful airline. Concerning the theory, it can be stated that airlines that are based on characteristics, which can be considered as "True LCC", are in the European market and are more likely to be successful than LCC airlines that are more focused on a hybrid model. The exact cost savings and profits have to take place in the case studies of the airlines. However, a single-type, young aircraft fleet seems to be more profitable than operating different aircraft types, as all the airlines that are on the "Successful" side have this in common. Additionally, high seat occupancy seems to be contributing to the success of the airline as well.

\section{Conclusions}

This research showed that the airline industry is growing quickly since 2010, as is described in the introduction, based on International Civil Aviation Organization (ICAO) (2018) in its annual report about 2017. Since the financial crisis of 2008 and 2009, the airline industry started growing and has nearly doubled in the number of passengers [83-86]. However, the airline industry has proven to be vulnerable to issues such as oil crises, financial crises, and the 9/11-terrorist attacks, and immediately showed a decline or a stop of growth. This research provided insight into the current development 
problems of the airline industry on its fastest-growing business model. It shows that an increase in oil prices is still one of the causes of serious airline troubles. However, airlines can counter this with a newer, more fuel-efficient fleet and successful fuel-hedging practices.

Issues of a whole other type are personnel problems, such as strikes. It is hard to find one exact reason for this issue. In the case of Ryanair, one of the airlines in this research, the reasons given by the pilots are a demand for a better salary, better rosters, and a base location closer to their homes. Furthermore, there are fleet problems, based on unexpected, required aircraft repairs and late deliveries of new aircraft. Airlines are forced to lease aircraft, which is a costly event. The last issue, airport capacity limitation, will affect every airline. Whether it is a limited runway capacity, aircraft stand capacity, or noise reduction measures. It will cause airports to run out of available slots for airlines. Given the high growth rate of the industry, the prices for a slot will go up. Airlines can counter this by flying to other airports (for example, secondary airports or by operating a modern, quieter aircraft).

As is visible from the conclusions given above, factors of LCCs can play a role in countering the negative effects of the development problems for airlines [11,12,87-95]. Flying to secondary airports of London, rather than the congested London Heathrow, operating a modern fleet, and achieving high load factors can counter effects. Machine problems, like engine problems such as Norwegian faced or late aircraft delivery (Primera Air), are difficult to prevent. It will delay the development of the airline and cause extra costs. Another risk is the stop of investments in an airline; this is, however, more risk for airlines that make a (structural) loss. Only Norwegian seems to have a riskier position on this issue.

The TOPSIS revealed as well that Wizz Air is the only airline meeting all the LCC criteria, whereas Ryanair and easyJet changed their business models during strategy changes. Wizz and Ryanair are both the most successful airlines of the group, with easyJet being in a third place. Subsidiary LCCs as Eurowings, Vueling, and Transavia are performing worse and are flying in general with the oldest fleet. Although ranking low on meeting LCC criteria, airBaltic is profitable and growing. It is implementing a brand new, efficient fleet and will shift to a single-type fleet. Norwegian is, given its loss and sale of new aircraft, ranking low.

Based on this research, in general, it can be concluded that the LCC business model has the potential for success regarding profitability and growth while having the possibility to counter the effects of some of the development problems in the industry. The efficient use of materials and a focus on a single type of aircraft can contribute to the success of the airline. Ryanair could counter its major effects of the personnel strikes, since its operating model led to successfulness, whereas Norwegian had to sell aircraft to maintain its existence. A further case study for each airline is recommended to for in depth research of how airlines survive the major issues in the airline industry. This research has led to the possible direction for research in the form of the exact operating model and risk prevention measures of the airlines. The case study of Vueling might give different insights, as it is a subsidiary airline, which is not meeting the majority of the LCC criteria, while it still is the third regarding successfulness within this research. It also has a rather small fleet on order and has one of the lowest seat occupancies amongst the airlines in this research. Further research can also be located in the operating models of FSCs and their success. Case studies can also lead to the improved weighting of the criteria for the MCDM analyses.

Author Contributions: Conceptualization, J.S. and G.F.V.K.; methodology, J.S.; software, G.F.V.K.; validation, J.S., G.F.V.K. and V.D.; formal analysis, V.D.; investigation, G.F.V.K.; resources, V.D.; data curation, J.S. writing-Original draft preparation, G.F.V.K.; writing-Review and editing, V.D.; visualization, V.D.; supervision, J.S.; project administration, V.D.; funding acquisition, V.D. All authors have read and agreed to the published version of the manuscript.

Funding: This research received no external funding.

Conflicts of Interest: The authors declare no conflict of interest. The funders had no role in the design of the study; in the collection, analyses, or interpretation of data; in the writing of the manuscript, or in the decision to publish the results. 


\section{Appendix A}

Table A1. Full calculations of the LCC criteria TOPSIS.

\begin{tabular}{cccccccccccc}
\hline Data & C1 & C2 & C3 & C4 & C5 & C6 & C7 & C8 & C9 & C10 & C11 \\
\hline Weight & 0.091 & 0.091 & 0.091 & 0.091 & 0.091 & 0.091 & 0.091 & 0.091 & 0.091 & 0.091 & 0.091 \\
Wizz Air & 1.000 & 1 & 1 & 1 & 1 & 1 & 1 & 1 & 1 & 1 & 1 \\
Ryanair & 0.994 & 1 & 1 & 1 & 1 & 1 & 1 & 1 & 1 & 1 & 0 \\
Transavia & 1.000 & 1 & 1 & 1 & 0 & 1 & 0 & 1 & 0 & 0 & 0 \\
easyJet & 0.997 & 1 & 1 & 1 & 0 & 1 & 1 & 1 & 1 & 1 & 0 \\
Vueling & 1.000 & 0 & 1 & 1 & 0 & 1 & 0 & 1 & 0 & 0 & 0 \\
airBaltic & 0.400 & 0 & 1 & 1 & 0 & 1 & 0 & 1 & 0 & 0 & 0 \\
Eurowings & 0.748 & 0 & 1 & 1 & 0 & 1 & 0 & 1 & 0 & 0 & 0 \\
Norwegian & 0.802 & 0 & 1 & 1 & 0 & 1 & 0 & 1 & 1 & 0 & 0 \\
\hline
\end{tabular}

Table A2. Full calculations of the LCC criteria TOPSIS.

\begin{tabular}{cccccccccccc}
\hline Normalized & C1 & C2 & C3 & C4 & C5 & C6 & C7 & C8 & C9 & C10 & C11 \\
\hline Wizz & 0.397 & 0.577 & 0.354 & 0.354 & 0.707 & 0.354 & 0.577 & 0.354 & 0.500 & 0.577 & 1.000 \\
Ryanair & 0.394 & 0.577 & 0.354 & 0.354 & 0.707 & 0.354 & 0.577 & 0.354 & 0.500 & 0.577 & 0.000 \\
Transavia & 0.397 & 0.577 & 0.354 & 0.354 & 0.000 & 0.354 & 0.000 & 0.354 & 0.000 & 0.000 & 0.000 \\
easyJet & 0.396 & 0.000 & 0.354 & 0.354 & 0.000 & 0.354 & 0.577 & 0.354 & 0.500 & 0.577 & 0.000 \\
Vueling & 0.397 & 0.000 & 0.354 & 0.354 & 0.000 & 0.354 & 0.000 & 0.354 & 0.000 & 0.000 & 0.000 \\
airBaltic & 0.159 & 0.000 & 0.354 & 0.354 & 0.000 & 0.354 & 0.000 & 0.354 & 0.000 & 0.000 & 0.000 \\
Eurowings & 0.297 & 0.000 & 0.354 & 0.354 & 0.000 & 0.354 & 0.000 & 0.354 & 0.000 & 0.000 & 0.000 \\
Norwegian & 0.319 & 0.000 & 0.354 & 0.354 & 0.000 & 0.354 & 0.000 & 0.354 & 0.500 & 0.000 & 0.000 \\
\hline
\end{tabular}

Table A3. Full calculations of the LCC criteria TOPSIS.

\begin{tabular}{cccccccccccc}
\hline Weighted & C1 & C2 & C3 & C4 & C5 & C6 & C7 & C8 & C9 & C10 & C11 \\
\hline Wizz & 0.036 & 0.052 & 0.032 & 0.032 & 0.064 & 0.032 & 0.052 & 0.032 & 0.045 & 0.052 & 0.091 \\
Ryanair & 0.036 & 0.052 & 0.032 & 0.032 & 0.064 & 0.032 & 0.052 & 0.032 & 0.045 & 0.052 & 0.000 \\
Transavia & 0.036 & 0.052 & 0.032 & 0.032 & 0.000 & 0.032 & 0.000 & 0.032 & 0.000 & 0.000 & 0.000 \\
easyJet & 0.036 & 0.000 & 0.032 & 0.032 & 0.000 & 0.032 & 0.052 & 0.032 & 0.045 & 0.052 & 0.000 \\
Vueling & 0.036 & 0.000 & 0.032 & 0.032 & 0.000 & 0.032 & 0.000 & 0.032 & 0.000 & 0.000 & 0.000 \\
airBaltic & 0.014 & 0.000 & 0.032 & 0.032 & 0.000 & 0.032 & 0.000 & 0.032 & 0.000 & 0.000 & 0.000 \\
Eurowings & 0.027 & 0.000 & 0.032 & 0.032 & 0.000 & 0.032 & 0.000 & 0.032 & 0.000 & 0.000 & 0.000 \\
Norwegian & 0.029 & 0.000 & 0.032 & 0.032 & 0.000 & 0.032 & 0.000 & 0.032 & 0.045 & 0.000 & 0.000 \\
\hline
\end{tabular}

Table A4. Full calculations of the LCC criteria TOPSIS.

\begin{tabular}{cccccccccccc}
\hline$V^{+}$(Best) & 0.036 & 0.052 & 0.032 & 0.032 & 0.064 & 0.032 & 0.052 & 0.032 & 0.045 & 0.052 & 0.091 \\
\hline$V^{-}$(Worst) & 0.014 & 0.000 & 0.032 & 0.032 & 0.000 & 0.032 & 0.000 & 0.032 & 0.000 & 0.000 & 0.000 \\
\hline
\end{tabular}

Table A5. Full calculations of the LCC criteria TOPSIS.

\begin{tabular}{ccccc}
\hline Airline & $\boldsymbol{S}_{\boldsymbol{i}}{ }^{+}$ & $\boldsymbol{S}_{\boldsymbol{i}}^{-}$ & $\boldsymbol{P}_{\boldsymbol{i}}$ & Rank \\
\hline Wizz & 0 & 0.150025 & 1 & 1 \\
Ryanair & 0.091 & 0.119302 & 0.567533 & 2 \\
Transavia & 0.141 & 0.050349 & 0.262682 & 4 \\
easyJet & 0.123 & 0.100528 & 0.474484 & 3 \\
Vueling & 0.151 & 0.021655 & 0.127299 & 6 \\
airBaltic & 0.150 & 0 & 0 & 8 \\
Eurowings & 0.151 & 0.012572 & 0.077941 & 7 \\
Norwegian & 0.144 & 0.047719 & 0.252185 & 5 \\
\hline
\end{tabular}




\section{Appendix B}

Table A6. Full calculations of the successfulness TOPSIS.

\begin{tabular}{ccccccc}
\hline Data & C12 & C13 & C14 & C15 & C16 & C17 \\
\hline Weight & 0.1 & 0.05 & 0.15 & 0.4 & 0.1 & 0.2 \\
Wizz Air & 257 & 4.7 & 146 & 14.1 & 91.2 & 24 \\
Ryanair & 135 & 6.9 & 243 & 20 & 95.3 & 10.3 \\
Transavia & 0 & 8.2 & 115 & 5.6 & 90.6 & 11 \\
easyJet & 147 & 7.3 & 163 & 8.1 & 92.9 & 10.2 \\
Vueling & 45 & 7.2 & 112 & 12.7 & 84.7 & 6.5 \\
airBaltic & 36 & 9.4 & 70 & 5.8 & 76 & 22 \\
Eurowings & 4 & 11.1 & 137 & 2.3 & 79.9 & 77 \\
\hline
\end{tabular}

Table A7. Full calculations of the successfulness TOPSIS.

\begin{tabular}{ccccccc}
\hline Normalised & C12 & C13 & C14 & C15 & C16 & C17 \\
\hline Wizz & 0.752 & 0.217 & 0.345 & 0.463 & 0.369 & 0.277 \\
Ryanair & 0.395 & 0.319 & 0.569 & 0.656 & 0.385 & 0.119 \\
Transavia & 0.000 & 0.377 & 0.269 & 0.184 & 0.366 & 0.127 \\
easyJet & 0.366 & 0.337 & 0.382 & 0.266 & 0.375 & 0.118 \\
Vueling & 0.132 & 0.333 & 0.262 & 0.417 & 0.342 & 0.075 \\
airBaltic & 0.105 & 0.435 & 0.164 & 0.190 & 0.307 & 0.254 \\
Eurowings & 0.012 & 0.513 & 0.321 & 0.075 & 0.323 & 0.887 \\
Norwegian & 0.340 & 0.180 & 0.377 & -0.189 & 0.354 & 0.150 \\
\hline
\end{tabular}

Table A8. Full calculations of the successfulness TOPSIS.

\begin{tabular}{ccccccc}
\hline Weighted & C12 & C13 & C14 & C15 & C16 & C17 \\
\hline Wizz & 0.075 & 0.011 & 0.051 & 0.185 & 0.037 & 0.055 \\
Ryanair & 0.040 & 0.016 & 0.085 & 0.262 & 0.039 & 0.024 \\
Transavia & 0.000 & 0.019 & 0.040 & 0.073 & 0.037 & 0.025 \\
easyJet & 0.037 & 0.017 & 0.057 & 0.106 & 0.038 & 0.024 \\
Vueling & 0.013 & 0.017 & 0.039 & 0.167 & 0.034 & 0.015 \\
airBaltic & 0.011 & 0.022 & 0.025 & 0.076 & 0.031 & 0.051 \\
Eurowings & 0.001 & 0.026 & 0.048 & 0.030 & 0.032 & 0.177 \\
Norwegian & 0.034 & 0.009 & 0.057 & -0.075 & 0.035 & 0.030 \\
\hline
\end{tabular}

Table A9. Full calculations of the successfulness TOPSIS.

\begin{tabular}{ccccccc}
\hline$V^{+}$ & 0.085 & 0.009 & 0.075 & 0.262 & 0.039 & 0.177 \\
\hline$V^{-}$ & 0.025 & 0.026 & 0.000 & -0.075 & 0.031 & 0.015 \\
\hline
\end{tabular}

Table A10. Full calculations of the successfulness TOPSIS.

\begin{tabular}{cccc}
\hline $\mathbf{S}_{\mathbf{i}}{ }^{+}$ & $\mathbf{S}_{\mathbf{i}}{ }^{-}$ & $\mathbf{P}_{\mathbf{i}}$ & Rank \\
\hline 0.149 & 0.276 & 0.650 & 2 \\
0.158 & 0.346 & 0.687 & 1 \\
0.258 & 0.150 & 0.368 & 7 \\
0.225 & 0.189 & 0.457 & 4 \\
0.204 & 0.243 & 0.544 & 3 \\
0.243 & 0.156 & 0.391 & 6 \\
0.247 & 0.195 & 0.441 & 5 \\
0.372 & 0.052 & 0.122 & 8 \\
\hline
\end{tabular}




\section{References}

1. International Civil Aviation Organization. The World of Air Transport in 2017. Available online: https://www. icao.int/annual-report-2017/Pages/the-world-of-air-transport-in-2017.aspx (accessed on 5 December 2018).

2. International Civil Aviation Organization. Part 4-Regulatory content. In Manual on the Regulation of International Air Transport, 2nd ed.; Doc 9626; International Civil Aviation Organization: Montreal, QC, Canada, 2004.

3. International Civil Aviation Organization. Economic Development of Air Transport, Facts and Figures. Available online: https://www.icao.int/sustainability/Pages/Facts-Figures_WorldEconomyData.aspx (accessed on 21 November 2018).

4. $\quad$ Herremans, L. De Ontwikkeling van de Grote Low Cost Carriers in West-Europa Vanaf 2004: Een Economische Analyse; Vrije Universiteit Brussel: Brussels, Belgium, 2007. (In Dutch)

5. Vowles, T.M. The effect of low fare air carriers on airfares in the US. J. Transp. Geogr. 2000, 8, 121-128. [CrossRef]

6. Windle, R.; Dresner, M. Competitive responses to low cost carrier entry. Transp. Res. Part E Logist. Transp. Rev. 1999, 35, 59-75. [CrossRef]

7. Erkuş-Öztürk, H.; Terhorst, P. Variety of modes of governance of a global value. Tour. Geogr. 2010, 12, 217-245. [CrossRef]

8. Button, K. Low-cost airlines: A failed business model? Transp. J. 2012, 51, 197-219. [CrossRef]

9. Schlumberger, C.E.; Weisskopf, N. Ready for Takeoff? International Bank for Reconstruction and Development/The World Bank: Washington, DC, USA, 2014.

10. Dennis, N. End of the free lunch? The responses of tradional European airlines to the low-cost carrier threat. J. Air Transp. Manag. 2007, 13, 311-321. [CrossRef]

11. Klophaus, R.; Conrady, R.; Fichert, F. Low cost carriers going hybrid: Evidence from Europe. J. Air Transp. Manag. 2012, 23, 54-58. [CrossRef]

12. Doganis, R. Flying Off Course: Airline Economics and Marketing; Routledge: London, UK, 2009.

13. Miranda, M.; Baltazar, M.E.; Silva, J. Airlines performance and efficiency evaluation using a MCDA methodology. The case for low cost carriers vs legacy carriers. Open Eng. 2016, 6, 389-396. [CrossRef]

14. Ryanair. Annual Report FY 2018; Ryanair: Dublin, Ireland, 2018.

15. airBaltic. airBaltic Receives Tenth Airbus A220-300. Available online: https://www.airbaltic.com/en/airbalticreceives-tenth-airbus-a220-300 (accessed on 30 July 2018).

16. Ishikawa, K.; Loftus, J. Introduction to Quality Control; 3A Corporation: Tokyo, Japan, 1990.

17. Ryanair. Ryanair Cuts Fy19 Guidance by 12\% Due to Higher Oil Prices, Higher Eu261 Costs, \& Weaker Fares Due To Recent Strikes. Available online: https://corporate.ryanair.com/news/ryanair-cuts-fy19-guidanceby-12-due-to-higher-oil-prices-higher-eu261-costs-weaker-fares-due-to-recent-strikes/ (accessed on 1 October 2018).

18. BBC. Ryanair Pilots 'Reach Deal to end Strike'. BBC News, 23 August 2018. Available online: https: //www.bbc.com/news/world-europe-45280416 (accessed on 7 December 2018).

19. Tsang, A. Passengers are Stranded as Another European Airline Collapses. The New York Times. 2 October 2018. Available online: https://www.nytimes.com/2018/10/02/business/primera-air-collapse.html (accessed on 8 December 2018).

20. Slotnick, D. Primera Air, Which Sold $\$ 99$ Tickets from the US to Europe, is Filing for Bankruptcy and Shutting Down Operations. Business Insider. 1 October 2018. Available online: https://www.businessinsider.com/ primera-air-filing-for-bankruptcy-2018-10 (accessed on 8 December 2018).

21. The Associated Press. Air Berlin Files for Bankruptcy after Key Shareholder Pulls the Plug on Funding. CBC, 15 August 2018. Available online: https://www.cbc.ca/news/business/air-berlin-bankruptcy-protection-1. 4247874 (accessed on 9 December 2018).

22. Zuidberg, J.; Vinkx, K. Capacity Demand at Schiphol Airport in 2023; SEO Amsterdam Economics: Amsterdam, The Netherlands, 2018.

23. Benlic, U. Heuristic search for allocation of slots at network level. Transp. Res. Part C Emerg. Technol. 2018, 86, 488-509. [CrossRef] 
24. Cobbs, R.; Wolf, A. Jet Fuel Hedging Strategies: Options Available for Airlines and a Survey of Industrial Practices; Kellogg School of Management at Northwestern University: Evanston, IL, USA, 2004. Available online: http://www.kellogg.northwestern.edu/research/fimrc/papers/jetfuel.pdf (accessed on 9 December 2018).

25. Zuidberg, J. Identifying airline cost economies: An econometric analysis of the factors affecting aircraft operating costs. J. Air Transp. Manag. 2014, 40, 86-95. [CrossRef]

26. Mayor, K.; Tol, R.S. The impact of European climate change regulations on international tourist markets. Transp. Res. Part D Transp. Environ. 2010, 15, 26-36. [CrossRef]

27. Eurostat. Real GDP Growth Rate-Volume. Available online: https://ec.europa.eu/eurostat/tgm/table.do? tab=table\&init=1\&language $=$ en\&pcode $=$ tec00115\&plugin $=1$ (accessed on 10 December 2018).

28. International Air Transport Association (IATA). Economic Performance of the Airline Industry; International Air Transport Association: Montreal, QC, Canada, 2018.

29. Tzeng, G.H.; Huang, J.J. Multiple Attribute Decision Making: Methods and Applications; Chapman and Hall/CRC: Boca Raton, FL, USA, 2011.

30. Eurostat. Population on 1 January by Age Groups and Sex-Functional Urban Areas. 2016. Available online: http://appsso.eurostat.ec.europa.eu/nui/submitViewTableAction.do (accessed on 10 December 2018).

31. Deutsches Zentrum für Luft- und Raumfahrt. Low-Cost Monitor 2/2010; Deutsches Zentrum für Luft- und Raumfahrt: Cologne, Germany, 2010.

32. Flightradar24. Airlines. Available online: https://www.flightradar24.com/data/airlines (accessed on 30 November 2018).

33. Skyscanner. VNO-EIN. Available online: https://www.skyscanner.net/transport/flights/vno/ein/ 181213/?adults $=1 \&$ children $=0 \&$ adultsv2 $=1 \&$ childrenv2 $=\&$ infants=0 \&cabinclass $=$ economy \&rtn=0\& preferdirects $=$ true \&outboundaltsenabled $=$ false $\&$ inboundaltsenabled $=$ false $\&$ ref $=$ home\#details/175671812130715--31669-0-112 (accessed on 12 December 2018).

34. Skyscanner. VNO-AMM. Available online: https://www.skyscanner.net/transport/flights/vno/amm/ 181312/?adults=1\&children=0\&adultsv2=1\&childrenv2=\&infants=0\&cabinclass=economy\&rtn=0\& preferdirects $=$ false \&outboundaltsenabled $=$ false\&inboundaltsenabled $=$ false $\&$ ref $=$ home\#/ $($ accessed on 12 December 2018).

35. Skyscanner. EIN-KRK. Available online: https://www.skyscanner.net/transport/flights/ein/krk/ 181312/?adults $=1 \&$ children $=0 \&$ adultsv2 $=1 \&$ childrenv2 $=$ \&infants $=0 \&$ cabinclass $=$ economy $\&$ rtn $=0 \&$ preferdirects $=$ false\&outboundaltsenabled $=$ false\&inboundaltsenabled=false\&ref=home\#/ (accessed on 12 December 2018).

36. Skyscanner. AMS-PRG. Available online: https://www.skyscanner.net/transport/flights/ams/prg/181213/ ?adultsv2=1\&childrenv2=\&cabinclass=economy\&rtn=0\&preferdirects=true\&outboundaltsenabled= false\&inboundaltsenabled=false\#details/9451-1812131845--32356-0-15538-1812132015 (accessed on 12 December 2018).

37. Skyscanner. MAD-BCN. Available online: https://www.skyscanner.net/transport/flights/mad/bcn/ 181312/?adults $=1 \&$ children $=0 \&$ adultsv2 $=1 \&$ childrenv2 $=\&$ infants $=0 \&$ cabinclass $=$ economy \&rtn $=0 \&$ preferdirects=false\&outboundaltsenabled $=$ false\&inboundaltsenabled $=$ false $\&$ ref $=$ home\#/ $($ accessed on 12 December 2018).

38. Skyscanner. VNO-CDG. Available online: https://www.skyscanner.net/transport/flights/vno/cdg/190907? flexible_origin=true\&flexible_depart=direct\&adults $=1 \&$ children $=0 \&$ adultsv $2=1 \&$ childrenv $2=\&$ infants $=$ $0 \&$ cabinclass $=$ economy \&rtn=0 \&preferdirects=true\&outboundaltsenabled =false\&inboundaltsenabled $=$ false\#det (accessed on 12 December 2018).

39. Skyscanner. DUS-TXL. Available online: https://www.skyscanner.net/transport/flights/duss/berl/ 190906/?adults=1\&children=0\&adultsv2=1\&childrenv2=\&infants=0\&cabinclass=economy\&rtn=0\& preferdirects $=$ true \&outboundaltsenabled $=$ false\&inboundaltsenabled $=$ false $\&$ ref $=$ home\#details/111651909060625--32332-0-1 (accessed on 12 December 2018).

40. Skyscanner. VNO-ARN. Available online: https:/www.skyscanner.net/transport/flights/vno/arn/ 190909/?adults $=1 \&$ children=0\&adultsv2=1\&childrenv2=\&infants=0\&cabinclass=economy \&rtn=0\& preferdirects=false\&outboundaltsenabled $=$ false\&inboundaltsenabled=false\&ref=home\#/ $($ accessed on 12 December 2018).

41. airBaltic. Book a Flight. Available online: https://www.airbaltic.com/en-LT/index?opentab=FLT (accessed on 12 December 2018). 
42. Ryanair. Flights. Available online: https://www.ryanair.com/gb/en/ (accessed on 12 December 2018).

43. Wizz Air. Flights. Available online: https://wizzair.com/en-gb\#/ (accessed on 12 December 2018).

44. Vueling. Flights. Available online: https://www.vueling.com/en (accessed on 12 December 2018).

45. easyJet. Flight. Available online: https://www.easyjet.com/nl (accessed on 12 December 2018).

46. Norwegian Air Shuttle. Flight. Available online: https://www.norwegian.com/us/ (accessed on 12 December 2018).

47. Transavia. Homepage. Available online: https://www.transavia.com/en-EU/home/ (accessed on 12 December 2018).

48. Eurowings. Flight Search. Available online: https://www.eurowings.com/skysales/Search.aspx?culture=enGB (accessed on 12 December 2018).

49. Ryanair. Always Getting Better. Available online: https://www.ryanair.com/gb/en/useful-info/about-ryanair/ always-getting-better (published 2018) (accessed on 10 December 2018).

50. easyJet. Worldwide by easyJet. Available online: https://www.easyjet.com/en/worldwide (published 2018) (accessed on 10 December 2018).

51. Flightradar24. Airports. Available online: https://www.flightradar24.com/data/airports (accessed on 30 November 2018).

52. Thomson, N.; Baden-Fuller, C. Basic Strategy in Context; John Wiley \& Sons: Hoboken, NJ, USA, 2010.

53. Czudar, E.; Ruwińska, K.; Ruck, N. The Customers' Perception of Wizz Air, the Largest Low-Fare Low-Cost Airline in Central Eastern Europe; University of Halmstad: Halmstad, Sweden, 2007.

54. Gutierrez, O. Review of Transavia Holland flight Amsterdam to Barcelona in Economy. Flight Report, 10 October 2015. Available online: https:/flight-report.com/en/report/11916/Transavia_Holland_HV5133_ Amsterdam_AMS_Barcelona_BCN (accessed on 14 December 2018).

55. Loukas. Review of Air Baltic Flight Tallinn $\rightarrow$ Riga in Economy. Flight Report, 17 January 2016. Available online: https:/flight-report.com/en/report/12983/Air_Baltic_BT_314_Tallinn_TLL_Riga_RIX (accessed on 14 December 2018).

56. RL 777. Review of Norwegian Flight Stockholm $\rightarrow$ Oslo in Economy. Flight Report, 12 August 2017. Available online: https:/flight-report.com/en/report/26490/Norwegian-DY807-Stockholm-ARN-Oslo-OSL (accessed on 8 December 2018).

57. Guillbcn. Review of Vueling Airlines Flight Stockholm $\rightarrow$ Barcelona in Economy. Flight Report. 8 February 2018. Available online: https:/flight-report.com/en/report/32544/Vueling-Airlines-VY1266-Stockholm-ARNBarcelona-BCN (accessed on 14 December 2018).

58. Loukas. Review of Eurowings Flight Warsaw $\rightarrow$ Düsseldorf in Economy. Flight Report. 7 October 2017. Available online: https://flight-report.com/en/report/28171/Eurowings-EW-9725-Warsaw-WAW-D-sseldorfDUS (accessed on 14 December 2018).

59. Lufthansa Group. Annual Report 2017; Lufthansa Group: Frankfurt, Germany, 2018.

60. International Air Transport Association. Airline and Airport Code Search. Available online: https: //www.iata.org/publications/Pages/code-search.aspx (accessed on 5 December 2018).

61. Airfleets.net. Airline Fleet Ages. Available online: https://www.airfleets.net/ageflotte/fleet-age.htm (accessed on 30 November 2018).

62. Wizz Air. Destination Map. Available online: https://wizzair.com/en-gb/flights/map\#/ (accessed on 1 December 2018).

63. Transavia. Destinations. Available online: https://www.transavia.com/en-EU/destinations/ (accessed on 30 November 2018).

64. easyJet. Routemap. Available online: http://www.easyjet.com/en/routemap (accessed on 30 November 2018).

65. Eurowings. Destinations. Available online: https://www.eurowings.com/en/information/destinations.html (accessed on 30 November 2018).

66. Vueling. Destinations. Available online: https://www.vueling.com/en/we-are-vueling/destinations-andairports/destinations (accessed on 1 December 2018).

67. Norwegian Air Shuttle. Route Map. Available online: https://www.norwegian.com/us/route-map/ (accessed on 1 December 2018).

68. airBaltic. Destinations. Available online: https://www.airbaltic.com/en/destinations (accessed on 30 November 2018). 
69. airBaltic. airBaltic Reports Best Ever Operational Results in 2017. 2018. Available online: https://www. airbaltic.com/en/airbaltic-reports-best-ever-operational-results-in-2017 (accessed on 13 December 2018).

70. Wizz Air. Wizz Air Announces Order for 146 Airbus A320neo Aircraft. Wizz Air, 15 November 2017. Available online: https://wizzair.com/en-gb/information-and-services/about-us/news/2017/11/15/wizz-airannounces-order-for-146-airbus-a320neo-family-aircraft\#/ (accessed on 19 December 2018).

71. Norwegian Air Shuttle. Our Aircraft. Available online: https://www.norwegian.com/uk/about/our-story/ our-aircraft/ (accessed on 4 December 2018).

72. Skonnord, O.P. Corrected-Norwegian Air Sees Possible Airbus Aircraft Sales Before Year End. Reuters, 4 September 2018. Available online: https://www.reuters.com/article/norwegian-air-fleet/corrected-norwegian-air-seespossible-airbus-aircraft-sales-before-year-end-idUSL8N1VQ3J1 (accessed on 19 December 2018).

73. Kaminski-Morrow, D. IAG clears fleet expansion for recovering Vueling. Flightglobal, 31 July 2018. Available online: https://www.flightglobal.com/news/articles/iag-clears-fleet-expansion-for-recoveringvueling-439823/ (accessed on 19 December 2018).

74. Airbus. easyJet Orders Additional 17 A320neo. Available online: https://www.airbus.com/newsroom/pressreleases/en/2018/11/easyjet-orders-additional-17-a320neo.html (accessed on 20 November 2018).

75. Planespotters.net. Eurowings. Available online: https://www.planespotters.net/airline/Eurowings (accessed on 3 December 2018).

76. Ryanair. Ryanair Exercises 25 Boeing-Max-200 Options. 2018. Available online: https://corporate.ryanair. com/news/ryanair-exercises-25-boeing-max-200-options/ (accessed on 19 December 2018).

77. Ryanair. Destination List. Available online: https://www.ryanair.com/us/en/cheap-flight-destinations-list (accessed on 1 December 2018).

78. Norwegian Air Shuttle. Annual Report 2017; Norwegian Air Shuttle: Lysaker, Norway, 2018.

79. Wizz Air. Annual Report FY 2018; Wizz Air: Budapest, Hungary, 2018.

80. Air France-KLM. Full Year 2017 Results; Air France-KLM: Paris, France, 2018.

81. International Consilidated Airlines Group (IAG). Annual Report 2017; International Consolidated Airlines Group (IAG): London, UK, 2018.

82. easyJet. Annual Report FY 2017; easyJet: Luton, UK, 2017.

83. Mishenin, Y.; Koblianska, I.; Medvid, V.; Maistrenko, Y. Sustainable regional development policy formation: Role of industrial ecology and logistics. Enterp. Sustain. Issues 2018, 6, 329-341. [CrossRef]

84. Otter, C.; Watzl, C.; Schwarz, D.; Priess, P. Towards sustainable logistics: Study of alternative delivery facets. Entrep. Sustain. Issues 2017, 4, 460-476. [CrossRef]

85. Gerasimov, B.N.; Vasyaycheva, V.A.; Gerasimov, K.B. Identification of the factors of competitiveness of industrial company based on the module approach. Entrep. Sustain. Issues 2018, 6, 677-691. [CrossRef]

86. Batkovskiy, A.M.; Kalachikhin, P.A.; Semenova, E.G.; Telnov, Y.F.; Fomina, A.V.; Balashov, V.M. Conficuration of enterprise networks. Enterp. Sustain. Issues 2018, 6, 311-328. [CrossRef]

87. Korauš, A.; Mazák, M.; Dobrovič, J. Quantitative analysis of the competitiveness of Benelux countries. Entrep. Sustain. Issues 2018, 5, 1069-1083. [CrossRef]

88. Hilkevics, S.; Semakina, V. The classification and comparison of business ratios analysis methods. Insights Into Reg. Dev. 2019, 1, 47-56. [CrossRef]

89. Mahdiraji, H.; Govindan, K.; Zavadskas, E.; Hajiagha, S.H.R. Coalition or decentralization: A game-theoretic analysis of a three-echelon supply chain network. J. Bus. Econ. Manag. 2014, 15, 460-485. [CrossRef]

90. Lietuvnikè, M.M.; Vasilis Vasiliauskas, A.; Vasilienè-Vasiliauskienė, V.; Sabaitytè, J. Conceptual model for minimization of losses caused by illegal immigrants to road freight transport operators. Challenges to national defence in contemporary geopolitical situation. In Proceedings of the 1th International Scientific Conference: Challenges to National Defence in Contemporary Geopolitical Situation (CNDCGS-2018), Pabradè, Lithuania, 25-27 April 2018; pp. 167-173.

91. Singgalen, Y.A.; Sasongko, G.; Wiloso, P.G. Community participation in regional tourism development: A case study in North Halmahera Regency-Indonesia. Insights Into Reg. Dev. 2019, 1, 318-332. [CrossRef]

92. Zeibote, Z.; Volkova, T.; Todorov, K. The impact of globalization on regional development and competitiveness: Cases of selected regions. Insights Reg. Dev. 2019, 1, 33-47. [CrossRef]

93. Shevyakova, A.; Munsh, E.; Arystan, M. Information support for the development of tourism for the diversification of the economy of Kazakhstan. Insights Reg. Dev. 2019, 1, 138-154. [CrossRef] 
94. Chkalova, O.; Efremova, M.; Lezhnin, V.; Polukhina, A.; Sheresheva, M. Innovative mechanism for local tourism system management: A case study. Entrep. Sustain. Issues 2019, 6, 2052-2067. [CrossRef]

95. Yunus, E.; Susilo, D.; Riyadi, S.; Indrasari, M.; Putranto, T.D. The effectiveness marketing strategy for ride-sharing transportation: Intersecting social media, technology, and innovation. Entrep. Sustain. Issues 2019, 7, 1424-1434. [CrossRef]

(C) 2020 by the authors. Licensee MDPI, Basel, Switzerland. This article is an open access article distributed under the terms and conditions of the Creative Commons Attribution (CC BY) license (http://creativecommons.org/licenses/by/4.0/). 